УДК 616-007.15

\title{
МИГРИРУЮЩИЕ КЛЕТКИ МЕДУЛЛЯРНОГО ЗАЧАТКА НАДПОЧЕЧНИКОВ КАК ВОЗМОЖНЫЙ ПОВРЕЖДАЮЩИЙ АГЕНТ И ПУСКОВОЙ МЕХАНИЗМ В РАЗВИТИИ ПРЕЭКЛАМПСИИ И ЭКЛАМПСИИ
}

\author{
${ }^{1}$ Берников С.Ю., ${ }^{2}$ Захаров В.Б. \\ ${ }^{1}$ ГБУЗ «Детская городская клиническая больница им. 3.А. Башляевой департамента \\ здравоохранения г. Москвы», Москва; \\ ${ }^{2}$ ГБОУ ВПО «Российский национальный исследовательский медицинский университет \\ им. Н.И. Пирогова» Министерства здравоохранения РФ, Москва
}

\begin{abstract}
Проведен хронологический анализ ключевых моментов внутриутробного развития плода и плаценты для выявления наиболее значимых событий и возможных триггерных факторов для возникновения преэклампсии и эклампсии. При подробном рассмотрении результатов патологоанатомических исследований как мертворожденных плодов, так и умерших новорожденных от женщин, беременность которых осложнялась преэклампсией и эклампсией, был выявлен очень любопытный факт. Вне зависимости от срока внутриутробного развития или срока постнатального периода в таких случаях неизменно отмечался заметный дефицит массы надпочечников (гипоплазия надпочечников). В результате подробного анализа становления дефинитивной организации внутренних органов плода, в совокупности с собственными патологоанатомическими данными, можно предположить, что повреждающим агентом и пусковым механизмом в развитии преэклампсии и эклампсии с большой долей вероятности могут быть мигрирующие клетки медуллярного зачатка надпочечников.
\end{abstract}

Ключевые слова: мигрирующие клетки медуллярного зачатка надпочечников, плацента, эклампсия, мозговое вещество надпочечников плода, преэклампсия

\section{MIGRATING CELLS OF MEDULLAR ADRENAL SPROUT AS A POSSIBLE DAMAGING AGENT AND STARTING MECHANISM IN DEVELOPMENT OF PRE-ECLAMPSY AND ECLAMPSY \\ ${ }^{1}$ Bernikov S.Y., ${ }^{2}$ Zakharov V.B.}

${ }^{I}$ Children city clinical hospital of Z.A. Bashlyayeva of Moscow department of healthcare, Moscow; ${ }^{2}$ Russian national research medical university of N.I. Pirogov of Ministry of healthcare of Russian Federation, Moscow

\begin{abstract}
Chronological analysis of key moments of intrauterine embryo and placenta development has been carried out in order to reveal the most significant and possible trigger factors for emergence of pre-eclampsy and eclampsy. During a detailed examination of pathoanatomical study of stillborn embryos as well as deceased infants of women, whose pregnancy was complicated by pre-eclampsy or eclampsy, a curious fact was revealed. Regardless of intrauterine development term of term of postnatal period for such cases one characteristic was typical - a visible deficit of adrenal mass (hyporplasia of adrenal glands). As a result of analyzing formation of definite organization of internal embryo organs in combination with pathoanatomical data, we can suppose that a damaging agent and triggering mechanism in development of pre-eclampsy and eclampsy are most likely migrating cells of medullar adrenal sprout.
\end{abstract}

Keywords: migrating cells of medullar adrenal sprout, pre-eclampsy, eclampsy, brain substance of embryo adrenal glands, placenta

Преэклампсия и эклампсия являются в высшей степени важной проблемой в акушерской науке и практике. Однако, до сих пор этиология и патогенез таких состояний не ясны. В настоящее время существует достаточно много различных теорий и взглядов на этот вопрос. Так, еще в 1935 году Лина Соломоновна Штерн рассматривала развитие эклампсии в результате нарушения проницаемости гематоэнцефалического барьера плода и как следствие проникновение плодовых нейроспецифических белков (НСБ) в кровяное русло материнского организма с образованием иммунных комплексов и повреждением эндотелия сосудов матери. Отдельные положения этой теории имеют подтверждения во многих клинических исследованиях. Так как ярким клиническим симптомом эклампсии являются судороги, особое внимание было уделено изучению центральной нервной системы. В результате масштабных исследований выявлено, что как в сыворотке крови беременных с эклампсией, так и у рожденных ими детей достоверно повышены нейроспецифические белки [11]. Данный неоспоримый факт усилил позиции этой теории, однако другие положения не выдерживают критики с морфологической точки зрения развития плода и плаценты. Другие авторы связывают развитие эклампсии с действием неких полифункциональных токсических ве- 
ществ, в качестве которых могут выступать продукты метаболизма фето-плацентарного комплекса[3]. Третья группа исследователей связывает возможное развитие эклампсии c нарушением инвазии цитотрофобласта в спиральные артерии матки [5]. В общей сложности существует более тридцати теорий возникновения эклампсии, среди которых выделяют и генетические факторы (дефекты генов: 7q36, - eNOS, 7q23-ACE, HLA, AT2P1, C677Т- полиморфизм).

Несмотря на результаты многочисленных фундаментальных исследований, вопрос о триггерных факторах развития преэклампсии и эклампсии остается открытым. Например, почему ранее 22 недели гестации преэклампсия не развивается? Для ответа на этот вопрос мы подвергли тщательному анализу все ключевые моменты гистологического развития тканей и органов плода и плаценты как на этом сроке, так и предшествующему ему.

Сравнительная оценка внутриутробного развития центральной нервной системы и гематоэнцефалического барьера, в совокупности с собственными патологоанатомическими данными не показала убедительных ключевых событий для возникновения преэклампсии на сроке 22 недель. Дифференцировка центральной и периферической нервной системы уже к 10 неделе достигает такого структурного уровня, что предплод (с 57 по 70-е сутки) в отличие от эмбриона может проявлять координированные моторные реакции на эндо- и экзогенные воздействия, а к 25 неделе внутриутробного развития кора полушарий приобретает строение сходное с мозгом взрослого человека [6].

При физиологическом течении беременности на 17-20 неделе гестации идет вторая волна инвазии цитотрофобласта, в результате которой объем маточно-плацентарного кровотока увеличивается в 6 раз (до 300 мл/мин). Основным типом ворсин в это время являются промежуточные незрелые ворсины с типичными стромальными каналами, а эпителиально-капиллярная дистанция на сроке 20 недель составляет в среднем 22,4 мкм. Особое внимание следует обратить на то, что клетки Кащенко-Гофбауэра, демонстрируют в это время явные черты атрофии и дегенерации ядер и органелл цитоплазмы. Это связывают с завершением клеточного цикла популяцией клеток, возникших с первичными капиллярами из мезенхимальных клеток стромы ранних ворсин [6]. Так как клетки Кащенко-Гофбауэра выполняют роль макрофагов и вместе со стромальными каналами составляют своеобразный функциональный аналог лимфатической системы, то находясь на данном сроке гестации в фазе истощения, возникает явное снижение способности плаценты к утилизации чужеродных агентов.

Немаловажной особенностью углеводного обмена во внутриутробном периоде у эмбриона и плода является превалирование активности ферментов анаэробного гликолиза, как более филогенетически раннего пути распада углеводов [4]. Обусловлено это тем, что насыщение кислородом крови плода находится на минимальном уровне, а поступающий в межворсинчатое пространство кислород в значительной мере поглощается самой плацентой [9]. Интенсивная оксигенация головного мозга и тканей плода начинается только с развитием синцитио-капиллярных мембран в терминальных ворсинах, которые становятся наиболее многочисленными после 32 недели развития.

Таким образом, учитывая особенности метаболизма плода на разных сроках гестации, представляются сомнительными выводы авторов, акцентирующих внимание на ранней гипоксии плода, как наиболее значимому фактору, под воздействием которого происходит гибель нейронов головного мозга и выход НСБ в кровеносное русло.

При патологоанатомических исследованиях плодов и новорожденных от женщин, беременность которых сопровождалась преэклампсией и эклампсией, в головном мозге ни в одном случае не обнаружено гибели нейронов, и более того, гистоархитектоника соответствовала возрастной норме. Морфологические изменения плаценты в подобных случаях соответствовали хорошо описанным в литературе ранее - это и уменьшение массы плаценты, и нарушение созревания виллезного дерева. Во всех случаях наблюдалось повреждение ворсин, хроническая плацентарная гипертензия I-II стадии с выраженным нарушением маточно-плацентарного кровообращения (множественные крупные инфаркты различной степени давности).

Особенно интересным нам показался тот факт, что у всех плодов и новорожденных, от женщин с преэклампсией и эклампсией, вне зависимости от срока гестации, мертворождения или срока жизни, неизменно отмечался заметный дефицит массы надпочечников (гипоплазия надпочечников).

Становление дефинитивной организации мозговых клеток надпочечников очень растянутый во времени процесс как для отдельной клетки, так и особенно для всей их популяции. Начиная с 16 недели и до рождения в надпочечнике человека наряду с почти зрелыми хромаффинными клетками можно встретить малодифференцированные элементы, а также клетки на разных промежуточных этапах дифференцировки. 
Эмбриональным источником мигрирующих клеток медуллярного зачатка надпочечников является нейроэктодерма. Затем предшественники мозгового вещества обнаруживаются в нервном гребне, после чего переселяются в ганглионарную пластинку. Это очень мелкие клетки (6-7 мкм), по своей организации выглядят довольно однородными, с высоким содержанием нуклеопротеидов $[2,1,14]$, значительным количеством рибосом $[2,14]$ и отсутствием реакции на хром. К началу врастания элементов мозгового вещества в интерреналовое тело можно выделить три типа клеток: симпатогонии, симпатобласты и хромаффинобласты. Однако такое обозначение клеточных форм признается не всеми авторами. Так Н.А. Смиттен (1972), предприняв тщательный цитологический анализ состава мигрирующих клеток медуллярного зачатка, пришла к выводу, что в качестве исходной «стволовой» клетки данной популяции можно выделять так называемую недифференцированную клетку нейрального зачатка, которая дает два ростка - нейробластический (источник симпатических нервов) и спонгиобластический - в составе, которого глиальные и хромаффинные клетки. Процесс миграции и внедрения элементов мозгового вещества продолжается вплоть до момента рождения. Клетки активно мигрируют к периферии закладки надпочечника и внедряются в формирующееся корковое вещество надпочечника. Характер врастания симпатогоний и хромаффинобластов различен. Первые активно продвигаются по ходу трабекул корковой ткани, раздвигая интерреналовые клетки, а хромаффинобласты могут использовать для своего продвижения русло коры. Внедряющиеся мелкие группы клеток называют мозговыми шарами, хотя они и не всегда имеют шаровидную форму. Темные мозговые шары устремляются к центру закладки надпочечника. В секреторных гранулах эндокриноцитов уже на 8 неделе внутриутробного развития выявляется норадреналин, а способность к метилированию и появлению адреналина обнаруживается на 16 неделе [8].

Обращает на себя внимание то, что, достигнув центральной вены надпочечника на 20-22 неделе, мигрирующие клетки медуллярного зачатка надпочечников не столько выселяются и скапливаются вокруг нее, сколько уходят с током крови из органа и разносятся по организму плода [2]. Известно, что к моменту рождения значительная часть клеток находится в процессе миграции. Мозговое вещество интенсивно увеличивается за счет размножения клеток до семилетнего возраста, а полное его развитие завершается к 15 годам жизни.

При проведении иммуногистохимических исследований на экспрессию Хромогранина A (CgA) при 1000 кратном увеличении в надпочечнике плода и в плаценте были обнаружены морфологически идентичные клетки практически лишенные цитоплазмы с множественными мелкими гранулами. Такие клетки были обнаружены в стромальных каналах ворсин, среди синцитиотрофобласта и синцитиальных почек, в составе некоторых свободных симпластов, а так же свободно лежащие в межворсинчатом пространстве. Интересным оказался тот факт, что в большинстве ворсин, где в составе синцитиотрофобласта присутствовали такие элементы, наблюдалось повреждение ворсин.

По данным ряда авторов количество синцитиальных почек увеличивается при преэклампсии $[15,16]$, а морфометрические исследования свидетельствуют и об увеличении их диаметра, в отличие от синцитиальных почек в плацентах при неосложненном течении беременности [16]. Известно, что свободные симпласты уходят в венозную систему матки. По современным представлениям образование свободных симпластов процесс естественный и физиологический. В течение суток в легкие беременной попадает около 100000-150000 свободных симпластов [7], где они разрушаются, высвобождая эмбриональную ядерную ДНК, которая поступает в кровоток матери [7, 12, 13].

Еще одним важным наблюдением оказалось достоверно более высокое содержание катехоламинов в плацентах женщин с преэклампсией, а величина артериальной гипертензии коррелирует со степенью тяжести преэклампсии и с изменением концентрации катехоламинов в структурах плаценты [10].

Таким образом, хронологический анализ событий, связанных с развитием мозгового вещества надпочечников позволяет предположить, что повреждающим агентом и пусковым механизмом в развитии преэклампсии и эклампсии с большой долей вероятности могут быть мигрирующие клетки медуллярного зачатка надпочечников.

\section{Список литературы}

1. Артишевский А.А. К вопросу о морфологии и гистохимии надпочечных желез человека в эмбриогенезе: Автореф. дис. ... канд. мед. наук. - Минск, 1964.

2. Волкова О.В., Пекарский М.И. Эмбриогенез и возрастная гистология внутренних органов человека. - М.: Медицина, 1976. - 416 с

3. Глуховец Б.И., Глуховец Н.Г. Патология последа. СПб.: ГРААЛЬ, 2002. -448 с. 
4. Патологическая анатомия болезней плода и ребенка: руководство для врачей в 2 т. / под ред. Т.Е. Ивановской, Л.В. Леоновой.- Т.1 - 2-е изд., перераб. и доп. - М.: Медицина, 1989. - $384 \mathrm{c}$.

5. Кветной И.М, Айламазян Э.К., Лапина Е.А., Колобов А.В. Сигнальные молекулы - маркеры зрелости плаценты. - М.: МЕДпресс-информ, 2005. - 96 с.

6. Под ред. Милованова А.П., Савельева С.В. Внутриутробное развитие человека: руководство для врачей. - М.: МДВ, 2006. - 384 c.

7. Милованов А.П. Патология системы матьплацента-плод: руководство для врачей. - М.: Медицина 1999. $-448 \mathrm{c}$

8. Пекарский М.И., Захаров В.Б. Общая и возрастная гистология человека: Этюды. - М.: Экон-информ, 2014. - 243 с.

9. Савельева Г.М., Федорова М.В., Клименко П.А., Сичинава Л.Г. Плацентарная недостаточность. - М.: Медицина 1991. $-276 \mathrm{c}$

10. Смирнова Т.Л., Драндров Г.Л., Сергеева В.Е. Содержание катехоламинов в структурах плаценты у женщин с плацентарной недостаточностью и гестозом // Вестник Чувашского университета. - 2011. - № 3. - С.425-429.
11. Чехонин В.П., Дмитриева Т.Б., Жирков Ю.А. Иммунохимический анализ нейроспецифических антигенов. - М.: Медицина, 1999. - 416 с.

12. Burton G.J., Jones C.J. Syncytial knots, sprouts, apoptosis, and trophoblast deportation from the human placenta, Taiwan J Obstet Gynecol, 2009, no.48 (1), pp.28-37.

13. Burton G.J. Deportation of syncytial sprouts from the term human placenta // Placenta, 2011, no. 32(1), pp.96-98.

14. Hervonen A. Development of catecholaminestoring cells in human fetal paraganglia and adrenal medulla. A histochemical and electron microscopic study, Acta Physiol., 1971, Suppl., no. 367, p. 94.

15. Rajakumar A., Cerdeira A.S., Rana S., Zsengeller Z., Edmunds L., Jeyabalan A., Hubel C.A., Stillman I.E., Parikh S.M., Karumanchi S.A. Transcriptionally active syncytial aggregates in the maternal circulation may contribute to circulating soluble fms-like tyrosine kinase 1 in preeclampsia, Hypertension, 2012. no. 59(2), pp.56-64.

16. Sankar K.D., Bhanu P.S., Kiran S., Ramakrishna B.A., Shanthi V. Vasculosyncytial membrane in relation to syncytial knots complicates the placenta in preeclampsia: a histomorphometrical study, Anat Cell Biol., 2012, no.45(2), pp.86-91. 